\title{
Ethology of Holcocephala calva (Loew, 1872) (Diptera: Asilidae) in Northeastern Florida, U.S.A.
}

\author{
D. Steve DENNIS † \\ 1105 Myrtle Wood Drive, St. Augustine, Florida 32086-4838, U.S.A. \\ e-mail: dstevedennis@msn.com \\ ORCID ID: 0000-0002-4832-4026
}

\begin{abstract}
Holcocephala calva (Loew, 1872) forages primarily from dead twig tips, capturing and immobilizing prey in flight or in a hover near the foraging/feeding site. Identified prey is in eight orders (Araneae, Blattodea (Isoptera), Coleoptera, Diptera, Hemiptera, Hymenoptera, Lepidoptera, and Psocoptera), with Hymenoptera (42.3\%) and Diptera (33.1\%) making up 75.4\%. Mating occurs in the tail-to-tail position. Females oviposited by dropping one egg at a time onto the ground. Holcocephala calva exhibit a daily rhythm of activity with peak periods between 6:00-10:00 AM of foraging, male searching flights for females with which to mate, mating, and ovipositing. Grooming occurs throughout the day. The most common grooming type consisting of the hind tarsi and tibiae being rubbed together and one or both hind tarsi and tibiae being used to stroke the sides of the abdomen. Habitat, flight patterns, daytime and nighttime resting behavior, light levels and vision, and predators and parasites also are discussed.
\end{abstract}

Key words: behavior, robber flies, Diptera, Asilidae.

Dennis, D. S. (2021). Ethology of Holcocephala calva (Loew, 1872) (Diptera: Asilidae) in Northeastern Florida, U.S.A. Journal of the Entomological Research Society, 23(3), 257-277. 


\section{INTRODUCTION}

Holcocephala is predominantly a genus of Neotropical robber flies with 40 described species (Carrera, 1958; Geller-Grimm, 2021 January 4). There are three Nearctic species: H. abdominalis (Say, 1823), H. calva (Loew, 1872), and H. fusca Bromley, 1951. These three species are usually found in mesic habitats such as along margins of streams, fields, and woods (Scarbrough, 1982) and wet meadows. They occur from the eastern United States west to eastern Texas, Kansas and Nebraska (Fisher \& Wilcox, 1997; Martin \& Wilcox, 1965).

Some behavior and habitat information has been published on all three Nearctic species: H. abdominalis (Baker \& Fischer, 1975; Blanton, 1939; Brimley, 1922; Bromley, 1931, 1946, 1950; Johnson, 1976; McAtee \& Banks, 1920; Scarbrough, 1974, 1982); H. calva (Baker \& Fischer, 1975; Bromley, 1931; McGravy \& Baxa, 2011; Scarbrough, 1974, 1982); and H. fusca (Dennis, 1979; Douglass \& Wehling, 2016; Fabian, Sumner, Wardill, Rossoni, \& Gonzalez-Bellido, 2018; Wardill, Fabian, Pettigew, Stavenga, Nordström \& Gonzalez-Bellido, 2017).

This paper provides information on the ethology of $H$. calva in the Moses Creek Conservation Area (MCCA) in St. Augustine (St. Johns County) in northeastern Florida. The main behaviors described are flight patterns, resting, foraging and feeding, mating, ovipositing, grooming, and daily rhythm of activity. Habitat, prey, light levels and vision, and predators and parasites are also discussed.

\section{MATERIALS AND METHODS}

In the MCCA, H. calva was studied from 22.04.2020-24.12.2020; and 09.03.2021-14.04.2021. Observations involved an average of 7 individuals per day, each for up to 7 hours. Total number of hours of observation equaled approximately 146 .

Holcocephala calva was studied by the author standing and observing single flies for as long as possible in order to collect information on their diurnal activities. Additionally, the author would slowly walk around a study area and observe the specific activities of individual flies, primarily in order to collect prey and to locate mating pairs and ovipositing females. Pentax Papilio $8.5 \times 21$ binoculars were used to observe flies so as not to disturb them.

Most prey were collected when prey were dropped into a net placed beneath the feeding robber flies that had ceased to feed. Collected prey were placed in glass vials with labels indicating the date, time, and location. It was difficult to accurately determine the sex of the robber flies because of their height on vegetation, and so this was not recorded. After prey were pinned, they were examined in the laboratory with a Wild Heerbrugg M8 stereomicroscope with an incident light base, a 1.6x objective, and a $20 x$ focusing eyepiece for magnifications up to $160 x$. The eyepiece was equipped with a $5 \mathrm{~mm} / 100$ division reticle for measuring the prey. The eyepiece reticle was calibrated using a dual axis $1 \mathrm{~mm} / 100$ division/0.01 mm and linear $50 \mathrm{~mm} / 500$ division/0.1 mm multi-function scale/stage micrometer. 
Ethology of Holcocephala calva (Loew, 1872) (Diptera: Asilidae) in Northeastern Florida

While in the field, a hand-held Cooper-Atkins DPP400W Digital Thermometer was used to take air temperatures. A Dwyer Hand-Held Wind Meter measured wind speed. Also a hand held UYIGAO Digital Light Meter (UA-962) measured light levels in lux, the metric International System of Units (SI). One lux equals one lumen/square meter and 0.0929 foot candle in the Imperial System.

\section{RESULTS AND DISCUSSION}

\section{Morphology}

Holcocephala calva is a small, 7.5-9.4 mm ( $\mathrm{n}=20 ; 10$ males and 10 females) long, blackish-gray species. Its head is dark brown to black with a sparse, white mystax that is confined to the oral margin. Head broader than thorax and compressed anterio-posteriorly. The thorax is white and arched, in particular the anterior $1 / 2$, and the scutum is dark gray to black. The scutellum has a grayish pollinose margin without bristles. The wings are covered with black microtrichiae and the veins are black. The legs are dark reddish yellow to reddish brown, and the femora and tibiae are darker distally. The abdomen is brownish with distinct grayish bands on the posterior margins of the first three segments, which are also constricted. The female terminalia do not have apical spines or acanthophorites.

\section{Habitat}

Holcocephala calva was found at three locations in the MCCA: (1) along an electrical transmission line (corridor/road (Red Trail)) in the Moses Creek floodplain and along the tree line between the floodplain and the mesic flatwoods vegetation community; (2) along the edge of a floodplain of a perennial unnamed tributary northwest of Moses Creek between roller chopped sandhill and scrubby flatwoods communities; and (3) west of Hidden Creek along a road (Yellow Trail) in an upland mixed forest community. The vegetation communities are shown in Table 1. In all three habitats a number of individuals (10-14) were found close together, within $20-45 \mathrm{~cm}$ of each other. Bromley (1946), Johnson (1976), LaPierre (2000), and Scarbrough (1982) also commented on large numbers of Holcocephala congregating in small areas.

The habitat in the Moses Creek floodplain (Fig. 1) extends approximately $54.7 \mathrm{~m}$ to the north of the Creek along the tree line with the approximate $33.8 \mathrm{~m}$ wide transmission line corridor to the east and forest immediately to the west. The dominant vegetation is groundsel tree (Baccharis halimifolia (L.)), sweetgum (Liquidambar styraciflua L.), southern bayberry/wax myrtle (Morella (Myrica) cerifera (L.) Small), dahoon holly (Ilex cassine L. var. cassine), saw palmetto (Arecaceae, Serenoa repens (W. Bartram)), and red maple (Acer rubrum L.). After heavy rains, some of the vegetation hangs over or is resting in $10-15 \mathrm{~cm}$ deep water.

The habitat $7.6 \mathrm{~m}$ to the east of the unnamed tributary to Moses Creek is in an open area approximately $20.9 \mathrm{~m}^{2}$ in size surrounded by taller trees and other vegetation. The dominant vegetation in the habitat is muscadine vine (Vitis rotundifolia Michx.), common buttonbush (Cephalanthus occidentalis (L.)), dahoon holly, and southern bayberry/wax myrtle. 


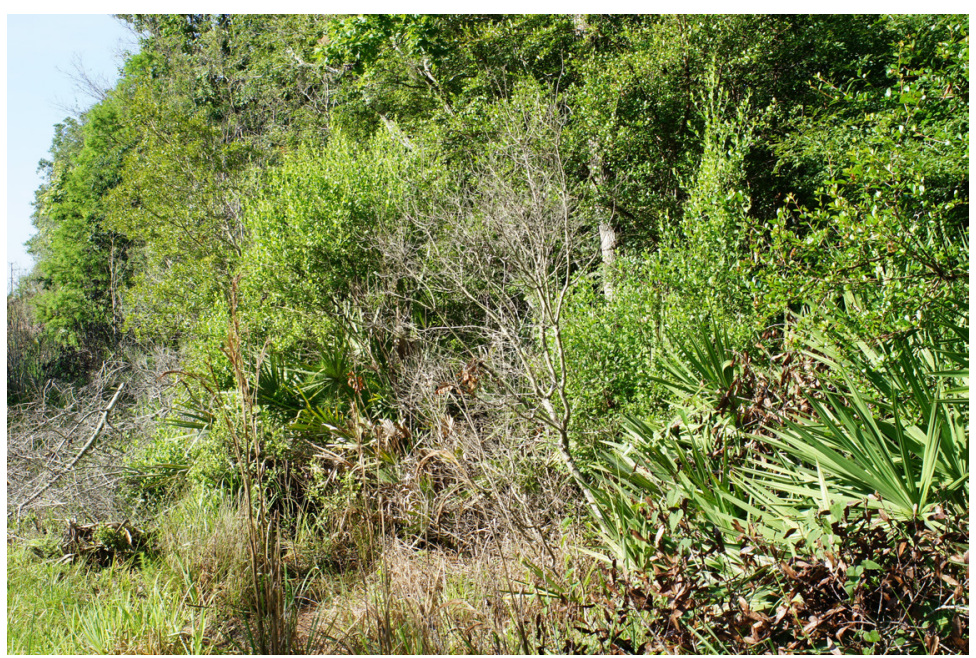

Fig. 1. Holcocephala calva habitat along road in Moses Creek floodplain (Photograph: D.S. Dennis, 29 May 2020, 8:52 AM).

Table 1. Vegetation communities in which Holcocephala calva was studied in the Moses Creek Conservation Area.

\begin{tabular}{|c|c|c|c|}
\hline Vegetation Type & \multicolumn{3}{|c|}{ Vegetation Community } \\
\hline $\begin{array}{l}\text { Family/Genus/Species/Common } \\
\text { Name }\end{array}$ & $\begin{array}{l}\text { Moses Creek Floodplain Marsh and } \\
\text { Along Edge of Mesic Flatwoods }\end{array}$ & $\begin{array}{l}\text { Perennial Unnamed } \\
\text { Tributary to Moses Creek }\end{array}$ & $\begin{array}{l}\text { West of Hidden Creek Along } \\
\text { Road in Upland Mixed Forest }\end{array}$ \\
\hline \multicolumn{4}{|l|}{ Altingiaceae } \\
\hline $\begin{array}{l}\text { Liquidambar styraciflua L./ } \\
\text { Sweetgum }\end{array}$ & $X^{1}$ & $-^{2}$ & $\mathrm{x}$ \\
\hline \multicolumn{4}{|l|}{ Aquifoliaceae } \\
\hline $\begin{array}{l}\text { Ilex cassine (L.) var. cassine/ } \\
\text { Dahoon }\end{array}$ & $x$ & $x$ & $x$ \\
\hline Ilex glabra (L.) A. Gray/Gallberry & - & - & $x$ \\
\hline $\begin{array}{l}\text { llex opaca Alton var. opaca / } \\
\text { American holly }\end{array}$ & - & $\mathrm{x}$ & - \\
\hline \multicolumn{4}{|l|}{ Arecaceae } \\
\hline $\begin{array}{l}\text { Sabal palmetto (Walter) Lodd. ex } \\
\text { Schult. \& Schult. f./Cabbage palm }\end{array}$ & - & $x$ & - \\
\hline $\begin{array}{l}\text { Serenoa repens (W. Bartram) Small/ } \\
\text { Saw palmetto }\end{array}$ & $x$ & $x$ & $x$ \\
\hline \multicolumn{4}{|l|}{ Asteraceae } \\
\hline $\begin{array}{l}\text { Baccharis halimifolia (L.)/Groundsel } \\
\text { tree; sea myrtle }\end{array}$ & $x$ & - & $x$ \\
\hline $\begin{array}{l}\text { Coreopsis leavenworthii Torr. \& A. } \\
\text { Gray/ Leavenworth's tickseed }\end{array}$ & $x$ & - & - \\
\hline $\begin{array}{l}\text { Erechtites hieraciifolius (L.) Raf. Ex } \\
\text { DC.IAmerican burnweed }\end{array}$ & $x$ & - & $x$ \\
\hline $\begin{array}{l}\text { Eupatorium capillifolium (Lam.) } \\
\text { Small ex Porter \& Britton/Dogfennel }\end{array}$ & $x$ & $x$ & $x$ \\
\hline Symphyotrichum sp./Aster & - & - & $\mathrm{x}$ \\
\hline
\end{tabular}


Ethology of Holcocephala calva (Loew, 1872) (Diptera: Asilidae) in Northeastern Florida

Table 1. Continued.

\begin{tabular}{|c|c|c|c|}
\hline Vegetation Type & \multicolumn{3}{|c|}{ Vegetation Community } \\
\hline $\begin{array}{l}\text { Family/Genus/Species/Common } \\
\text { Name }\end{array}$ & $\begin{array}{l}\text { Moses Creek Floodplain Marsh and } \\
\text { Along Edge of Mesic Flatwoods }\end{array}$ & $\begin{array}{l}\text { Perennial Unnamed } \\
\text { Tributary to Moses Creek }\end{array}$ & $\begin{array}{l}\text { West of Hidden Creek Along } \\
\text { Road in Upland Mixed Forest }\end{array}$ \\
\hline \multicolumn{4}{|l|}{ Cupressaceae } \\
\hline $\begin{array}{l}\text { Taxodium ascendens Brongn./ } \\
\text { Pond-cypress }\end{array}$ & $x$ & - & $x$ \\
\hline \multicolumn{4}{|l|}{ Cyperaceae } \\
\hline Cyperus spp./Flatsedges & $\mathrm{x}$ & $x$ & - \\
\hline \multicolumn{4}{|l|}{ Dennstaedtiaceae } \\
\hline $\begin{array}{l}\text { Pteridium aquilinum } \mathrm{L} \text {. (Kuhn) var. } \\
\text { pseudocaudatum (Clute) Clute ex A. } \\
\text { Heller/Tailed bracken }\end{array}$ & - & - & $x$ \\
\hline \multicolumn{4}{|l|}{ Ericaceae } \\
\hline $\begin{array}{l}\text { Lyonia ferruginea (Walter) Nutt./ } \\
\text { Rusty lyonia }\end{array}$ & - & - & $x$ \\
\hline $\begin{array}{l}\text { Vaccinium myrsinitas Lam./Shiny } \\
\text { blueberry }\end{array}$ & - & - & $x$ \\
\hline \multicolumn{4}{|l|}{ Euphorbiaceae } \\
\hline $\begin{array}{l}\text { Triadica sebifera (L.) Small/ } \\
\text { Popcorntree; Chinese tallowtree }\end{array}$ & $\mathrm{x}$ & - & $\mathrm{x}$ \\
\hline \multicolumn{4}{|l|}{ Fabaceae } \\
\hline $\begin{array}{l}\text { Sesbania herbacea (Mill.) McVaugh/ } \\
\text { Danglepod }\end{array}$ & $x$ & - & - \\
\hline $\begin{array}{l}\text { Sesbania sericea (Wild.) Link/ } \\
\text { Silky sesban }\end{array}$ & $x$ & - & - \\
\hline \multicolumn{4}{|l|}{ Fagaceae } \\
\hline $\begin{array}{l}\text { Quercus geminate Small/Sand } \\
\text { live oak }\end{array}$ & - & - & $x$ \\
\hline Quercus laurifolia Michx./Laurel oak & $x$ & - & $x$ \\
\hline Quercus myrtifolia Willd./Myrtle oak & $x$ & $x$ & $x$ \\
\hline Quercus nigra L./Water oak & - & - & $x$ \\
\hline \multicolumn{4}{|l|}{ Gelsemiaceae } \\
\hline $\begin{array}{l}\text { Gelsemium sempervirens (L,) W.T. } \\
\text { Alton/Yellow (Carolina) jessamine }\end{array}$ & $x$ & - & $x$ \\
\hline \multicolumn{4}{|l|}{ Lauraceae } \\
\hline $\begin{array}{l}\text { Persea borbonia (L.) Spreng. var } \\
\text { borbonia/Red bay }\end{array}$ & $\mathrm{x}$ & - & $x$ \\
\hline \multicolumn{4}{|l|}{ Magnoliaceae } \\
\hline Magnolia virginiana L./Sweetbay & - & $x$ & - \\
\hline \multicolumn{4}{|l|}{ Myricaceae } \\
\hline $\begin{array}{l}\text { Morella (Myrica) cerifera (L.) Small/ } \\
\text { Southern bayberry; wax myrtle }\end{array}$ & $x$ & $x$ & $x$ \\
\hline \multicolumn{4}{|l|}{ Osmundaceae } \\
\hline $\begin{array}{l}\text { Osmundastrum cinnamomeum (L.) } \\
\text { C. Pres// Cinnamon fern }\end{array}$ & - & $\mathrm{x}$ & $\mathrm{x}$ \\
\hline
\end{tabular}


Table 1. Continued.

\begin{tabular}{|c|c|c|c|}
\hline Vegetation Type & \multicolumn{3}{|c|}{ Vegetation Community } \\
\hline $\begin{array}{l}\text { Family/Genus/Species/Common } \\
\text { Name }\end{array}$ & $\begin{array}{l}\text { Moses Creek Floodplain Marsh and } \\
\text { Along Edge of Mesic Flatwoods }\end{array}$ & $\begin{array}{l}\text { Perennial Unnamed } \\
\text { Tributary to Moses Creek }\end{array}$ & $\begin{array}{l}\text { West of Hidden Creek Along } \\
\text { Road in Upland Mixed Forest }\end{array}$ \\
\hline \multicolumn{4}{|l|}{ Osmundaceae } \\
\hline $\begin{array}{l}\text { Osmundastrum cinnamomeum (L.) } \\
\text { C. Presl/ Cinnamon fern }\end{array}$ & - & $x$ & $x$ \\
\hline \multicolumn{4}{|l|}{ Pinaceae } \\
\hline Pinus elliotti Engelm./Slash pine & - & - & $x$ \\
\hline Pinus serotina Michx./Pond pine & $x$ & $x$ & - \\
\hline \multicolumn{4}{|l|}{ Poaceae } \\
\hline $\begin{array}{l}\text { Andropogon glomeratus (Walter) } \\
\text { Britton et al. var glomeratus/Bushy } \\
\text { bluestem }\end{array}$ & - & - & $x$ \\
\hline Andropogon sp./Bluestem & $x$ & - & - \\
\hline $\begin{array}{l}\text { Eustachys glauca Chapm./ } \\
\text { Saltmarsh fingergrass }\end{array}$ & $x$ & - & - \\
\hline Setaria sp./Foxtail & $x$ & - & $x$ \\
\hline \multicolumn{4}{|l|}{ Pontederiaceae } \\
\hline Pontederia cordata L./Pickerelweed & $x$ & - & - \\
\hline \multicolumn{4}{|l|}{ Rosaceae } \\
\hline $\begin{array}{l}\text { Rubus cuneifolius Pursh/Sand } \\
\text { blackberry }\end{array}$ & $x$ & - & - \\
\hline Pontederia cordata L./Pickerelweed & $x$ & - & - \\
\hline \multicolumn{4}{|l|}{ Rubiaceae } \\
\hline $\begin{array}{l}\text { Cephalanthus occidentalis (L.)/ } \\
\text { Common buttonbush }\end{array}$ & - & $x$ & - \\
\hline \multicolumn{4}{|l|}{ Sapindaceae } \\
\hline Acer rubrum L./Red maple & $x$ & $x$ & - \\
\hline \multicolumn{4}{|l|}{ Smilacaceae } \\
\hline $\begin{array}{l}\text { Smilax auriculata Walter/Earleaf } \\
\text { greenbrier vine }\end{array}$ & - & - & $x$ \\
\hline $\begin{array}{l}\text { Smilax bona-nox L./Saw greenbrier } \\
\text { vine }\end{array}$ & $x$ & $x$ & - \\
\hline $\begin{array}{l}\text { Smilax laurifolia L./Laurel greenbrier } \\
\text { vine }\end{array}$ & $x$ & - & $x$ \\
\hline \multicolumn{4}{|l|}{ Viburnaceae } \\
\hline \multicolumn{4}{|l|}{$\begin{array}{l}\text { Viburnum obovatum Walter/Small } \\
\text { leaf arrow wood; Walter's viburnum }\end{array}$} \\
\hline \multicolumn{4}{|l|}{ Vitaceae } \\
\hline $\begin{array}{l}\text { Vitis rotundifolia Michx./ Muscadine } \\
\text { grape vine }\end{array}$ & $x$ & $x$ & $x$ \\
\hline
\end{tabular}

\section{1- present; 2 - not present}


The habitat west of Hidden Creek consists of an open area north of the road, approximately $50.9 \mathrm{~m}^{2}$ in size, $15.8 \mathrm{~m}$ from the Creek, and an area along the southern edge of the road that extends from approximately 3.7-34.7 $\mathrm{m}$ from the Creek. The dominant vegetation in the open area is muscadine vine, Chinese tallow tree (Tridica sebifera (L.) Small), bushy bluestem (Andropogon glomeratus (Walter) Britton et al.), and dog fennel (Eupatorium capillifolium (Lam.) Small ex Porter \& Britton). Along the southern edge of the road the dominant vegetation is sweetgum, southern bayberry/ wax myrtle, muscadine vine, earleaf greenbrier vine (Smilax auriculata Walter), and laurel greenbrier vine (S. laurifolia L.).

Holcocephala calva are most frequently found on dead twig tips of muscadine vine, dahoon holly, groundsel tree, sweetgum, southern bayberry/wax myrtle and Chinese tallow tree. However, a few individuals would briefly land on muscadine vine leaves and tips of live vine tendrils.

Hull (1962), commented that Holcocephala are "...frequently abundant in swamp areas where they are found on the tips of twigs and leaves among rank undergrowth." Brimley (1922) noted that $H$. abdominalis in North Carolina can be found "... in rank herbage in damp shady places..." The term rank indicates grassland or marsh vegetation that has grown abundantly, without being cut or grazed for some time.

McGravy \& Baxa (2011) found $H$. calva in an oak-hickory forest that had not been burned for at least 5 years. Bromley (1931) observed that $H$. calva is generally associated with $H$. abdominalis "...in rather damp situations, alighting on the tips of twigs and grasses." Bromley $(1946,1950)$ also noted that $H$. abdominalis can be found in low country or moist edges of meadows or low woodland landing on the tips of dead twigs or grass with a number of individuals occurring on the same plant or low shrub.

Back (1909) found $H$. abdominalis in damp grass areas clinging to grass stems. McAtee and Banks (1920) said that $H$. abdominalis is "...usually seen perched on tips of grass blades in damp situations," and Blanton (1939) found this species at the edge of a field and near woods on the dead stems of yankeeweed (as dog fennel; Asteraceae, Eupatorium compositifolium Walter). Johnson (1976) studied $H$. abdominalis in a field surrounded by woods. Dennis (1979) found $H$. fusca on the edge of a forested area next to the lawn associated with apartment buildings.

Where $H$. calva and $H$. abdominalis have been found occupying the same habitat, the former is usually less abundant than the latter (McAtee \& Banks, 1920; Bromley, 1931; Baker \& Fischer, 1975; Scarbrough, 1982).

Fisher (2009) indicated that in Central America Holcocephala perch on twig and plant tips and "...show distinct preferences in forest type and light exposure. Some Holcocephala species prefer open, sunny habitats, such as edges of forest or sparse second-growth vegetation. Other species are only found in more closed habitat, such as mature forest, including the shaded forest understory."

\section{Flight patterns}

Robber fly flight patterns have been classified as orientation, investigatory, foraging, and searching flights (Dennis \& Lavigne, 1975). Orientation flights are often short 
flights around a robber fly's location to change its position or field of vision and are not directed towards potential prey. Investigatory flights are directed toward potential prey without the robber fly making contact. Because $\mathrm{H}$. calva prey are difficult to see by a human observer, it is believed that many orientation flights are investigatory flights, and it is not possible to distinguish between the two and so they are discussed together.

Foraging flights occur when an individual makes contact with potential prey. Searching flights are when males search for receptive females with which to mate, with the males often weaving in and out of the vegetation.

Holcocephala calva orientation/investigatory and foraging flights are also discussed below under Foraging and Feeding Behavior. Searching flights are discussed under Courtship and Mating Behavior.

\section{Daytime and nighttime resting behavior}

During the daytime $H$. calva rests and forages from 1-3 mm diameter twig tips 32.5 $\mathrm{cm}$ to $4.65 \mathrm{~m}$ (average $1.8 \mathrm{~m} ; \mathrm{n}=80$ ) above the ground. Individuals are active in both sun and shade, although their habitats are in the shade of surrounding vegetation most of the day, in particular along the unnamed tributary to Moses Creek and near Hidden Creek. Bromley (1950) said that H. calva "rests on tips of twigs of bushes and small trees." When their habitats are in the sun, most $H$. calva rest and forage with their backs to the sun.

Other species of Holcocephala are generally found on vegetation at heights from $20 \mathrm{~cm}$ to $5 \mathrm{~m}$ above the ground (Dennis, 1979; Johnson, 1976; Scarbrough, 1982). Johnson (1976) observed $H$. abdominalis moving to lower levels $(10-30 \mathrm{~cm}$ above the ground) in vegetation as temperatures decreased later in the flight season. Scarbrough (1982) also found that $H$. abdominalis foraged from perches on lower vegetation than did $H$. calva.

When $H$. calva is ready to "rest," they back down or crawl around to the top, side or underside (Fig. 2) of the branch 1-30 cm (average $5 \mathrm{~cm} ; \mathrm{n}=53$ ) from the tip and hold their bodies close to and parallel to the branch. They rest in one location for an average of 7.7 minutes (range 1/2-40 minutes; $n=22$ ) before moving to another location to rest or resume foraging. One individual moved nine times over a period of 1 hour and 31 minutes. While resting, individuals are motionless or move very little and do not react to other insects that fly around them.

Many species of robber flies maintain their body temperature by changing their position in relation to the sun, resting on the shady side of vegetation, or flattening themselves against the substrate they are on (Dennis, 2018; Dennis \& Lavigne, 1975; Lavigne \& Holland, 1969). A few H. calva move to the shade of the twig they are on when the sun shines on them and then move back to the top of the branch when they are no longer in the sun. Also, some individuals turn their right or left sides to the sun.

When resting and/or feeding, a number of $H$. calva expel a drop of creamy-white to shiny white liquid from their anus. Lehr (1958) commented that the expulsion of liquid from the anal opening is quite common in robber flies. 


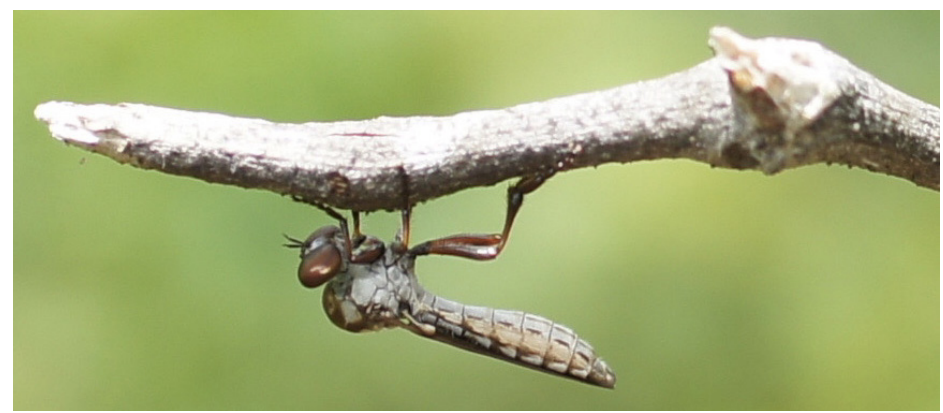

Fig. 2 Holcocephala calva in daytime and nighttime resting position (Photograph: D.S. Dennis, 3 July 2020, 1:39 PM).

Some $H$. calva spend the night on the same twigs where they rest and forage during the daylight hours. However, in the unnamed tributary to Moses Creek habitat most move down to slightly lower twigs $1.5-1.9 \mathrm{~m}$ above the ground. At night individuals are usually positioned on the top of or underneath the twig 1-17.5 cm (average 5.4 $\mathrm{cm} ; \mathrm{n}=11$ ) from the tip, with their bodies held flat against the twig. They remain in this position until approximately 45-60 minutes after sunrise when they stand up and often groom their hind tarsi and tibiae before they start daily activities.

Dennis (1979) observed $H$. fusca spending the night on twig tips or flattened against the top or side of a twig 1-3.5 cm from the tip.

Because the $H$. calva habitats are in limited areas surrounded by vegetation, there is usually very little wind to disturb the resting and foraging individuals and the wind was typically calm to less than $3.2 \mathrm{~km} / \mathrm{hr}$.

\section{Foraging and feeding behavior}

When foraging, $H$. calva, (1) stand up on or near a twig tip with their bodies parallel to the twig or at a $30-45^{\circ}$ angle with their fore and mid legs extended and the tips of their abdomen often touching the twig, or (2) hang vertically from the twig tip with their head and at least one-half of their thorax above the twig tip (Fig. 3). They usually face open areas and forage from one position/location for an average of 69.6 minutes (range from 2 minutes to 7 hours; $n=29$ ). Thus, they capture prey that are usually outlined or backlit against a blue or bright sky. Scarbrough (1982) observed similar foraging behavior for both $H$. calva and $H$. abdominalis, although the latter foraged more frequently in sunlight. The majority of $H$. fusca prey were captured in sunlit areas (Dennis, 1979).

Female $H$. calva appear to remain on the same twig tips for longer periods of time than do males and they also may forage from the same twig tip for several days. It is assumed that males move around more because they are performing searching flights for receptive females with which to mate.

Holcocephala calva make orientation/investigatory flights within $3.75-37.5 \mathrm{~cm}$ (average $21 \mathrm{~cm} ; \mathrm{n}=26$ ) of their perch and usually return to the same perch. These 
flights are made all around and generally at the same level as their perch. Only three orientation/investigatory flights were made $7.5-12.5 \mathrm{~cm}$ below their perch.

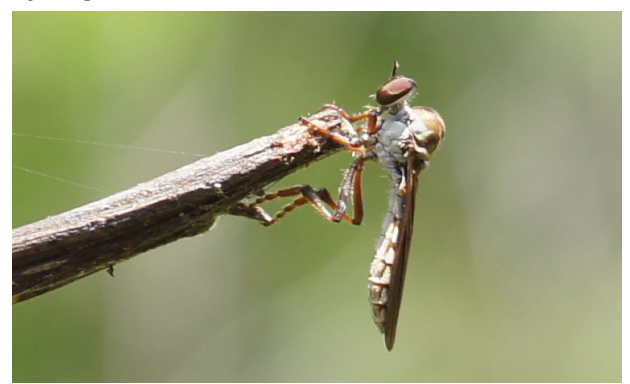

Fig. 3. Holcocephala calva in foraging position (Photograph: D.S. Dennis, 12 June 2020, 12:10 PM).

Ten foraging flights were observed when prey was captured in flight and released, usually in a hover adjacent to or slightly below the foraging perch while the individual manipulated the prey with all six tarsi. There was only one prey capture and release without the individual hovering and manipulating its potential prey. Seven of these prey capture and release flights were made around and at the same level as the foraging perch, within an average $21.8 \mathrm{~cm}$ (range $15-37.5 \mathrm{~cm}$ ) of the perch. Two flights were in front of and 7.5 and $10 \mathrm{~cm}$ below the perch, and one flight was straight up $12.5 \mathrm{~cm}$ above the perch. After releasing the discarded prey, two individuals held their wings open to a $45^{\circ}$ angle as if "frustrated" that they had not captured an acceptable prey. One individual also immediately re-captured the prey that it had just released and again discarded it. Sometimes Holopogon phaeonotus Loew, 1874 exhibits similar wing spreading when captured prey are not acceptable (Dennis, 2014).

Based on 54 prey captures, $H$. calva captured 36 of its prey at the same level and $5-45 \mathrm{~cm}$ (average $21.3 \mathrm{~cm}$ ) around its foraging position. Ten prey were captured $20-38 \mathrm{~cm}$ (average $27.8 \mathrm{~cm}$ ) in front of or to the right or left, and $6.3-45 \mathrm{~cm}$ (average $19.8 \mathrm{~cm}$ ) above or below the foraging position. Eight prey were captured $8.8-45 \mathrm{~cm}$ (average $19.5 \mathrm{~cm}$ ) straight above the individuals foraging position. Scarbrough (1982) said that $H$. calva and $H$. abdominalis capture over approximately $88 \%$ of their prey between 15-100 cm in front of and to one side or the other of their foraging sites. Holcocephala fusca successfully captured its prey within $12.5-30 \mathrm{~cm}$ in front of and to the side of its foraging position (Dennis, 1979).

Wardill et al. (2017) found that $H$. fusca uses a constant bearing angle (CBA) strategy to initially fly an interception course with its prey. When an individual is within $29 \mathrm{~cm}$ of the prey, the robber fly "locks-on" to the prey and adjusts its velocity and direction so that it comes alongside the prey to make its capture.

After prey capture, the proboscis is usually immediately inserted in the prey and the individual lands on the same foraging perch. Only a few $\mathrm{H}$. calva hover next to or $2.5-10 \mathrm{~cm}$ below their feeding site and manipulate the prey with all six tarsi before inserting their proboscis. Hovering and manipulating prey usually lasts only a few seconds, but two individuals hovered and manipulated prey for 13-15 seconds. 
During feeding, prey hang free from the individual's proboscis without being held by the tarsi (Fig. 4). Some prey, such as Hymenoptera (Eucharitidae, Orasema sp. and winged Formicidae) may be manipulated one or two times with all six tarsi and the proboscis reinserted in the prey as the individual hovers near the feeding site. Also, an individual will continue to observe other insects as they fly by, as indicated by rapid movements of its head and body. Similar behavior has been observed for other species of Holcocephala (Dennis, 1979; Scarbrough, 1982).

The average length of 10 male and female $H$. calva is $8.5 \mathrm{~mm}$. The average length of 88 prey is $2.4 \mathrm{~mm}$ with a range from $0.8-5.6 \mathrm{~mm}$. This results in a mean predator to prey ratio of 3.5 , which indicates that $H$. calva is approximately $31 / 2$ times larger than its prey. Scarbrough (1982) said that the mean predator to prey ratios for $\mathrm{H}$. calva and $H$. abdominalis is 3.7 and 3.4 , respectively. The overall mean predator to prey ratio for both $H$. fusca, (Dennis, 1979) and $H$. oculata is 3.5 ( LaPierre, 2000). Mean predator to prey ratios for other species of robber flies range from 0.9:1.0 to 8.4:1.0 (Dennis, 2016), with an overall mean of 2.8.

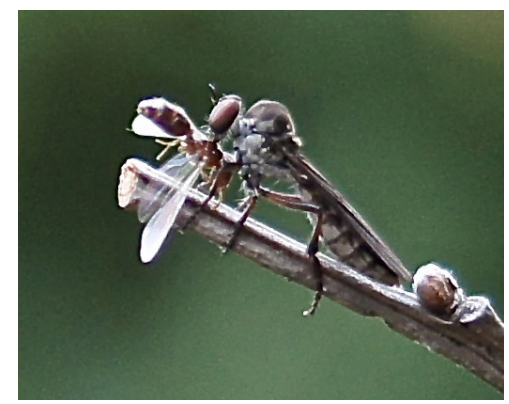

Fig. 4. Holcocephala calva with winged Pheidole navigans as prey (Photograph: D.S. Dennis, 23 June 2020, 7:01 AM).

Holcocephala calva feedings range from 1-36 minutes with an average of 10.7 minutes $(n=54)$. The time spent feeding generally correlates with prey length. Holcocephala calva fed on wasps (Eucharitidae, Orasema sp.) with lengths ranging from 2.15-3.00 mm (average, $2.39 \mathrm{~mm}$; $\mathrm{n=6}$ ), for 12-30 minutes (average 21.9 minutes). Long-legged flies (Dolichopodidae, Chrysotus sp.) with lengths ranging from 1.12-2.47 mm (average $1.69 \mathrm{~mm} ; \mathrm{n}=3$ ), were fed on for 4-25.5 minutes (average 14.2 minutes). As for a number of other species of robber flies, including $H$. fusca, the time spent feeding usually depends on prey length (Dennis, 1979, 2020).

At the completion of feeding, $H$. calva discards prey as follows, from most to least common: (1) it pushes prey off its proboscis with the fore tarsi while still at the feeding site (35.5\%; $n=43) ;(2)$ it allows prey to drop off its proboscis at the feeding site ( $29.8 \%$; $n=36) ;(3)$ it drops prey in flight and captures another prey $(24.8 \%$; $n=30) ;(4)$ it drops prey in flight, but does not capture another prey $(9.1 \%$; $n=11)$; and (5) while hovering and manipulating prey, it drops the prey $(0.8 \% ; n=1)$. Other species of Holcocephala use similar methods to discard prey (Dennis, 1979; Johnson, 1976; Scarbrough, 1982 ) with pushing prey off the proboscis at the feeding site being the most common. 
Thirty-nine interfeedings were observed with an average of 8.8 minutes and a range from 0-68.5 minutes. There were 20, 0-minute interfeedings when the robber flies dropped the prey in flight that they were feeding on and immediately captured another prey.

The theoretical number of prey an individual $H$. calva can feed on in one day can be calculated if one assumes that: (1) it continually forages and feeds between 6:00 AM and 3:00 PM (the time when $87.7 \%$ of the feedings were observed), and (2) it captures and feeds on prey every 19.5 minutes (which includes the average feeding and inter-feeding times). Therefore, over a 9-hour period an individual could feed on approximately 27 prey. However, it is of interest to note that one individual fed on five prey over 41.5 minutes and another fed on six prey over an 88 minute period.

This compares favorably with Scarbrough (1982) who noted that $H$. calva fed on prey for an average of 9.2 minutes and could dispatch approximately 25 prey per day. Holcocephala abdominalis (Scarbrough, 1982) and Holcocephala fusca (Dennis, 1979) fed on prey for an average of 8.6 and 10.9 minutes and approximately 22 and 26 prey per day, respectively. Dennis (2016) reported that other investigators estimate robber flies feed on 1 to 35 prey per day.

Some prey (in particular Diptera) ballooned or swelled while $H$. calva was feeding. This also was observed for $H$. fusca (Dennis, 1979). Lavigne \& Holland (1969) attributed prey ballooning to asilids pumping proteolytic enzymes and digested material in and out of prey. Also, during feeding some robber flies contract the first one to three segments of their abdomen.

Abdominal pumping (or contractions) has been associated with the pumping of enzymes and digested material while feeding on prey (Musso, 1968; Lavigne \& Holland, 1969), as well as thermoregulation (Morgan \& Shelly, 1988; Morgan, Shelly, \& Kimsey, 1985). No abdominal pumping was recorded for $H$. calva, $H$. abdominalis (Johnson, 1976), and H. fusca (Dennis, 1979)..

Of interest, Drukewitz et al (2018) have described and illustrated the hypothesized feeding process of robber flies starting with envenomation of the prey through feeding on the liquefied prey contents.

\section{Prey}

The following is a list of prey taken by $H$. calva with the number of prey following the date, if more than one.

ARANEAE, Unidentified, 02.05.20, 08.05.20, 22.08.20. BLATTODEA (Isoptera), Kalotermitidae (alate; winged): Calcaritermes nearcticus Snyder, 1933, 21.05.20. COLEOPTERA, Bostrichidae: Lyctus sp., 25.04.20; Curculionidae: Xyleborinus sp., 05.06.20; Xyleborinus, poss. saxsenii (Ratzeburg. 1837), 30.05.20; Xyleborus sp., prob. pubescens Zimmermann, 1868, 16.06.20, 27.06.20; Mordellidae: Tolidomordella discoidea (Meisheimer, 1845), 28.04.20 (2); Nitidulidae: unidentified, 25.5.20, 15.06.20. Staphylinidae: Proteinus sp., 25.05.20; 15.06.20. DIPTERA, Cecidomyiidae: unidentified, 28.04.20, 13.10.20; Ceratopogonidae: unidentified, 20.06.20; 
Chironomidae: unidentified, 05.08.20, 21.08 .20 (2), 07.10.20, 13.10.20; Chloropidae: unidentified, 27.04.20, 19.08.20; Dolichopodidae: Chrysotus sp., 28.04.20 (2), 01.05.20, 11.05.20, 20.05.20 (3), 21.05.20, 02.06.20, 09.06.20, 13.10.20; unidentified, 01.05.20; Empididae: unidentified, 18.05.20; Ephydridae: unidentified, 23.09.20; Hybotidae: Euhybos sp., 26.08.20; Syneches sp., 19.05.20, 17.06.20, 29.08.20; unidentified, 18.06.20; Muscidae: unidentified, 16.06.20; Phoridae: Borophaga sp., 13.10.20; Sciaridae: unidentified, 09.06.20 (2), 16.06.20, 18.06.20, 20.06.20, 19.08.20; Simuliidae: Simulium sp., 11.12.20; Unidentified Family, 02.06.20, 05.06.20 (2), 14.06.20, 16.06.20, 20.06.20 (2), 22.06.20, 26.06.20 (2), 27.06.20, 29.08.20, 16.09.20, 07.10.20 (3). HEMIPTERA, Cicadellidae: unidentified, 21.11.20 (2), Delphacidae: unidentified, 19.06.20 (2); Miridae: unidentified, 18.05.20, 25.05.20 (3), 09.06.20, 05.08.20. HYMENOPTERA, Chalcidoidea: unidentified, 02.05.20; Eucharitidae: Orasema sp., 27.04.20 (4), 28.04.20, 04.05.20 (5), 05.05.20 (4), 08.05.20 (3), 15.05.20 (3), 18.05.20, 23.05.20; unidentified, 17.06.20; Eupelmidae: unidentified, 09.06.20; Formicidae (alates; winged): Camponotus sp. poss. inaequalis Roger, 1863, 16.09.20; Crematogaster sp., 27.04.20, 27.05.20 (3), 29.05.20, 09.06.20; 11.06.20; Nylanderia sp., 05.06.20 (3), 27.06.20; Pheidole navigans Ford, 1901 (Fig. 4), 15.05.20, 27.05.20, 18.06.20; 20.06.20, 26.06.20; Solenopsis invicta Buren, 1972, 25.05.20, 11.06.20 (2), 16.06.20; unidentified: 01.05.20, 16.06.20 (3), 19.06.20, 22.06.20 (2), 23.06.20 (5), 26.06.20 (2), 27.06.20 (4), 08.07.20, 10.07.20, 05.08.20, 18.09.20; Unidentified Family, 19.05.20. LEPIDOPTERA, Tortricidae: Eucosma sp., 28.04.20, 02.05.20, 25.05.20, 09.06.20, 18.06.20. PSOCOPTERA: Unidentified, 27.04.20 (2), 04.05.20, 05.05.20, 08.05.20, 18.05.20, 17.06.20, 23.09.20 (2), 30.09.20. UNIDENTIFIED Order, 22.04.20, 25.04.20 (12), 27.04.20 (2), 28.04.20, 02.05.20, 04.05.20 (12), 05.05.20 (16), 08.05.20 (3), 15.05.20, 21.05.20 (5), 23.05.20 (4), 25.05.20 (3), 29.05.20 (4), 30.05.20 (22), 02.06.20 (3), 05.06.20 (17), 09.06.20 (5), 11.06.20 (8), 12.06.20 (3), 13.06.20 (3), 16.06.20, 17.06.20 (3), 18.06.20 (4), 22.06.20, 23.06.20 (4), 26.06.20 (3), 27.06.20 (2), 03.07.20 (5), 07.07.20, 08.07.20, 29.07.20, 05.08.20, 15.08.20 (2), 21.08 .20 (2), 16.09.20, 18.09.20, 30.09.20, 02.10.20, 13.10.20 (2).

Of the prey identified to at least Order, the majority are Hymenoptera $(42.3 \%)$, followed by Diptera (33.1\%), Coleoptera $(6.7 \%)$, Hemiptera and Psocoptera (each $6.2 \%)$, Lepidoptera (3.1\%), Araneae (1.8\%), and Blattodea (Isoptera, 0.6\%). Other investigators have documented Holcocephala feeding on insects representing the same orders (Johnson, 1976; Dennis, 1979; Scarbrough, 1982; LaPierre, 2000). Similarly, Scarbrough (1982) reported $H$. calva and $H$. abdominalis feeding primarily on Diptera followed by Hymenoptera. Johnson (1976) said that $H$. abdominalis fed mainly on Diptera and then Hymenoptera. Dennis (1979) also observed male $H$. fusca feeding mainly on Diptera and then Hymenoptera; whereas, females fed in the reverse order.

It is believed that $H$. calva captured the Araneae while they were ballooning or floating through the air on silk threads. Johnson (1976) observed $H$. calva "...feeding on a spiderling with a silk thread trailing from it." Dennis, Lavigne \& Dennis (2012) documented other species of robber flies capturing spiders while they were ballooning. 
For other species, McAtee and Banks (1920) indicated that $H$. abdominalis fed on Solenopsis sp. and Lasius sp. (Hymenoptera, Formicidae) while Bromley (1950) noted that they fed on Culicoides sp. (Diptera, Ceratopogonidae).

\section{Mating behavior}

Male $H$. calva perform searching flights for receptive females with which to mate. Searching flights consist of males flying around the twigs of branches in their habitat for $2-23$ seconds with an average of 8.6 seconds $(n=23)$. During searching flights, the males slowly fly with the femora of the fore- and mid-legs held up against the thorax, and the tibiae and tarsi hanging down at about a $30-45^{\circ}$ angle or the tibiae and tarsi are held closer to the thorax and extend forward. The hind legs also hang below the individual at about a $45^{\circ}$ angle. Male searching flights have been described for $\mathrm{H}$. fusca (Dennis, 1979) and H. oculata (LaPierre, 2000).

Like $H$. fusca (Dennis, 1979), male $H$. calva did not hover in front of or near females or exhibit courtship as described for $H$. abdominalis (Johnson, 1976) and H. oculata (LaPierre, 2000).

Holcocephala calva males attempt to initiate matings by landing on the dorsum of both males and females that are on twig tips. Non-receptive individuals spread their wings at a $30-90^{\circ}$ angle and sometimes curve their abdomen down and/or crawl on the twig away from the male. If the male does not fly off after landing on a non-receptive individual, the pair will fall off the twig and separate in flight or when they hit leaves of vegetation or the ground below. Before separating some males will attempt to clasp the genitalia of non-receptive individuals for several seconds. Also, males will repeatedly attempt to mate with the same non-receptive individuals. Dennis (1979) reported similar behavior for $H$. fusca.

When the male is able to successfully clasp a female's genitalia, he will then fall backwards to below the female in the tail-to-tail position (Fig. 5). In this position the wings of both the male and female are folded over their backs and the asilids remain still while mating. The male faces the opposite direction of the female or slightly to her side and his legs hang "below" his body. On one occasion one mating pair was in the tail-to-tail position when another male landed on the female and attempted to clasp her genitalia for 2 minutes before flying away.

At the completion of mating, the male usually swings up and grabs a nearby twig to the side of or below the female, and then unclasps the female. The male either then flies off or remains on the twig for up to 1.5 minutes before flying off. One male swung up and grabbed the female before unclasping her and flying off at the completion of mating.

Seven mating pairs were observed with four complete matings that lasted 18.0-19.5 minutes with an average of 18.9 minutes. Holcocephala fusca (Dennis, 1979) and $H$ oculata (LaPierre, 2000) also mate in the tail-to-tail position, with the latter mating for an average of 11 minutes.

Holcocephala calva mating pairs were observed at heights ranging from 1.1-3.3 $\mathrm{m}$ (average height of $2.1 \mathrm{~m}$ ) above the ground where air temperature ranged from $14.0-27.4^{\circ} \mathrm{C}$ (average of $20.1^{\circ} \mathrm{C}$ ). 


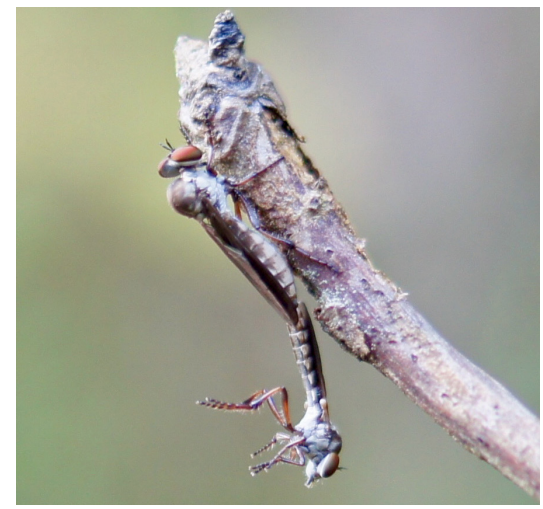

Fig. 5. Mating pair of Holcocephala calva in the tail-to-tail position with the female above and male hanging below (Photograph: D.S. Dennis, 30 September 2020, 8:37 AM).

\section{Oviposition behavior}

Four ovipositions were observed; females were on branch tips or up to $2.5 \mathrm{~cm}$ back from the tips on top of the branch with their abdomens slightly extended over the side of the branch. The females were approximately 1.4-1.5 m (average 1.5 m) above the ground. Three females each dropped one egg with their abdomens parallel to the ground. The fourth female quickly dipped her abdomen and dropped an egg. The eggs were a glistening light to dark amber and slightly elongate or oval with one end narrower than the other. It was not possible to recover the eggs because the ovipositions were being watched through binocularis. Holcocephala abdominals (Johnson, 1976) and H. fusca (Dennis, 1979) have similar eggs. Johnson (1976) suggested that the former species probably deposits eggs one at a time.

The ultrastructure of the chorion of the eggs of $H$. calva and $H$. abdominalis was described by Candan, Suludere, Hasbenli, Çağıran, Lavigne \& Scarbrough (2004). The chorion of the eggs of both species is thick, but $H$ calva had tall, thin, uniform ridges in a hexagonal pattern; whereas, $H$. abdominalis had low, thick, uniform ridges in a polygon pattern. The eggs also have aeropyles between the sculpturing on the chorion. Dennis (1979) also reported that $H$. fusca has hexagonal sculpturing on its chorion).

Candan et al. (2004) said that forest edge species such as $H$. calva and $H$. abdominalis have simple ovipositors and drop their eggs at random. They also indicated that the "eggs deposited in this manner are frequently, but temporarily, inundated with water." The sculptured chorions with aeropyles facilitates gas exchange by trapping gas bubbles on their surface.

The air temperatures at the heights of the $H$. calva ovipositions ranged from $21.3-27.8^{\circ} \mathrm{C}$ with an average of $24.6^{\circ} \mathrm{C}$.

\section{Grooming behavior}

Robber fly grooming behavior is often associated with other behaviors such as those following the completion of feeding, mating, and ovipositing. There are also 
species-specific variations in the sequence and frequency of grooming. Like other robber flies, $H$. calva always use the fore legs to groom their heads, and the hind legs to groom their wings, abdomen, and genitalia while resting and during feeding and mating. They never were observed grooming the thorax.

Holcocephala calva groom their faces more often within 2 hours after sunrise, after feeding on large prey, and at the completion of feeding after pushing prey off the proboscis with the fore tarsi. The face is groomed with the fore tarsi and tibiae, often while alternately moving each side of the head up and down. After grooming the face, the fore tarsi and tibiae are often rubbed together. This sequence of grooming is often repeated a number of times for up to 13 minutes after feeding. One individual also groomed its eyes with the fore tibiae after capturing a prey.

After mating, female $H$. calva groom their abdomens more than do males. The hind tarsi are typically first rubbed together and then the posterior $2 / 3$ of the abdomen is groomed from anterior to posterior. During grooming the abdomen is either straight or slightly curved down. After grooming the hind tarsi and tibiae may be rubbed together. The hind tarsi are also often rubbed together when an individual is feeding.

Following grooming of the abdomen, the wings are often groomed from anterior to posterior or outward, with the hind tibiae and tarsi. One individual groomed the wings using only the hind tibiae. The tops and bottoms of the wings are groomed with the wings closed or open to a $30-45^{\circ}$ angle to the body.

One female groomed the posterior part of her abdomen with her hind tarsi after ovipositing. She then rubbed her hind tarsi together.

Throughout the day the most common grooming is when the hind tarsi and tibiae are rubbed together and when one or both hind tarsi and tibiae are used to stroke the sides of the abdomen. As exhibited by $H$. abdominalis (Johnson, 1976) and $H$. fusca (Dennis, 1979), H. calva spent more time grooming its wings, abdomen and hind tarsi than its face and fore tarsi.

\section{Daily rhythm of activity}

Holcocephala calva exhibit a daily rhythm of activity with peak periods of foraging, male searching flights for females with which to mate, mating, and ovipositing between 6:00-10:00 AM (Fig. 6). The number of feeding individuals had a slight peak between 8:00-9:00 AM with a steady number (61.6\%) feeding between 7:00 AM-12:00 noon. The majority $(87.7 \%)$ of $H$. calva observed fed between 6:00 AM-3:00 PM.

Male searching flights peak $(62.9 \%)$ between $8: 00-9: 00 \mathrm{AM}$, with the majority (88.6\%) between 7:00-10:00 AM. Matings peak (85.8\%) between 6:00-9:00 AM. Ovipositing females have two peaks between 6:00-7:00 AM and 9:00-10:00 AM, with $50 \%$ each during these time periods.

\section{Light levels and vision}

Depending on cloud cover, parts or all of the Moses Creek habitat are in the sun from approximately 8:30 AM-1:45 PM. The tributary to Moses Creek and Hidden 
Creek habitats has intermittent periods (approximately 15-minute periods) of sun from 9:00 AM-4:00 PM and 8:15 AM-2:00 PM, respectively. When the habitats are in the sun, light levels vary from 8,300-100,000 lux (average 31,635; $n=8$ ); when parts of the habitats are in the shade or under a light cloud cover/haze, light levels vary from 1,034-5,967 lux (average 3,800 lux; $n=22$ ). These levels can be compared with typical full daylight, but not in direct sun light, levels that vary from 10,000-25,000 lux and direct sunlight levels that range from 32,000-100,000 lux (Lackey, 2016 January 28). Light levels in shade or under an overcast sky vary from 1,000-5,000 lux.

Holcocephala calva began feeding and mating early in the morning when light levels were low. At that time the individuals could barely be seen and appeared as dark objects. The first feeding and mating (6:20 AM and 6:13 AM, respectively) took place before sunrise which varied from 6:24-6:26 AM when light levels were 84.9-96.8 lux. These light levels are similar to levels measured for twilight (10.8 lux) and/or to a very dark day (107 lux) (Engineering ToolBox, 2004). Feeding also continued into the evening (last observed feeding, 8:06 PM with sunset at 8:23-8:30 PM) when light levels were 598.6-583.3 lux or levels for a very dark day to an overcast day $(1,075$ lux; Engineering ToolBox, 2004). The last orientation/investigatory flight observed, occurred at 8:42 PM when light levels were $8.1-8.4$ lux and the temperature was $24.8^{\circ} \mathrm{C}$. The individual flew $2.5-5.0 \mathrm{~cm}$ in front of and to the side of its perch for 7 seconds before relanding on its perch for the night. Johnson (1976) observed $H$. abdominalis with its first and last prey at 6:27 AM and 8:17 PM, respectively.

The first oviposition also occurred early in the morning at 6:47 AM, shortly after sunrise. At that time the light levels varied from 1,193-1,217 lux.

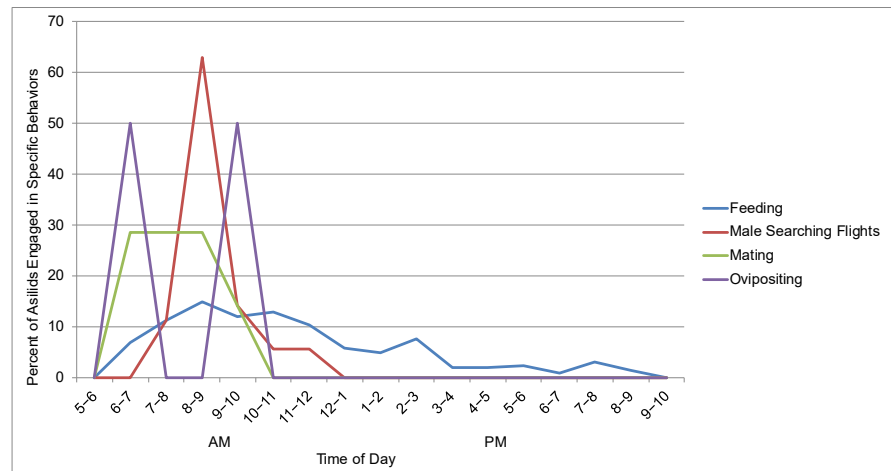

Fig. 6. Daily rhythm of activity of Holcocephala calva based on 326, 35, 7, and 4 observations for feeding, male searching flights, mating, and ovipositing, respectively.

Holcocephala calva continuing to be active when light levels are low indicates that they have good visual acuity and can see objects well even under low light conditions. Nation (2008) wrote that, "Insect compound eyes perform poorly in very dim light, but insects that are active at night or at dusk have special adaptations for vision in dim light. These may include wider facets and wider rhabdoms that increase sensitivity by up to 1-2 log units." 
The eyes of $H$. calva and $H$. abdominalis were examined and they both have mediofrontal enlarged facets (frontal enlarged-facet zones (EFZ)) similar to those reported for $H$. fusca (Douglass \& Wehling, 2016; Wardill et al., 2017). Land (1997) said that many insects (including robber flies and dragonflies) have acute zones (localized areas of high resolution) that are forward or upward pointing that are specialized for predation. Douglass \& Wehling (2016) indicated that the $H$. fusca frontal EFZ are associated with acute zones that represent a specialization of the frontal visual field. Wardill et al. (2017) commented that the behavioral, anatomical and optical data for $H$. fusca eyes show extremely specialized visual capabilities. They also wrote, "The extremely enlarged frontal ommatidia have facet lenses with extended focal lengths that focus incident light into unusually slender rhabdomeres... These specializations are known to optimize the spatial resolution of fly eyes, thus creating an area of high acuity, a fovea."

\section{Predators and parasites}

Lavigne, Dennis \& Gowen (2000) indicated that cannibalism is often reported for robber flies. However, it was not observed for $H$. calva during this study or by Scarbrough (1982). Cannibalism also has not been observed for $H$. abdominalis (Johnson, 1976; Scarbrough, 1982), H. fusca (Dennis, 1979), or H. oculata (LaPierre, 2000).

A female of the robber fly Ommatius floridensis Bullington \& Lavigne, 1984 captured one female $H$. calva.

While resting and foraging, $H$. calva individuals were disturbed by: (1) slender twig ants (Formicidae, Pseudomyrmex gracilis (Fab., 1804)); (2) blue dasher (Libellulidae: Pachydiplax longipennis (Burmeister, 1839)) and great blue skimmer (Libellulidae: Libellula vibrans (Fab., 1793)) dragonflies; (3) bumblebees (Apidae: Bombus sp.); (4) and honeybees (Apidae: Apis mellifera L., 1758). When disturbed the individuals would usually back down the twig $2.5-7.5 \mathrm{~cm}$ they were on and then resume their position on the twig tip after the intruder had left. A few individuals flew to a nearby twig tip when disturbed.

The author has observed mites on robber flies, in particular on the thorax. However, none were found on $H$. calva.

\section{Conclusions}

Holcocephala calva exhibits behavior similar to other species of Nearctic $(H$. abdominalis and $H$. fusca) and Neotropical $(H$. oculata) Holcocephala. This species rests on and forages primarily from dead twig tips. They often spend the night on the same twig tips. All prey are captured in flight and consists of Hymenoptera (42.3\%), Diptera (33.1\%), Coleoptera (6.7\%), Hemiptera and Psocoptera (each 6.2\%), Lepidoptera (3.1\%), Araneae (1.8\%), and Blattodea (Isoptera; 0.6\%). During feeding, prey (mostly Hymenoptera) may be manipulated with all six tarsi in a hover next to the feeding site. Mating occurs in the tail-to-tail position and females oviposit by dropping single eggs onto the ground. This species exhibits a daily rhythm of activity with peak 
Ethology of Holcocephala calva (Loew, 1872) (Diptera: Asilidae) in Northeastern Florida

feeding, male searching flights for females with which to mate, mating, and ovipositing early in the morning from 6:00-10:00 AM. Grooming behavior resembles that described for other species of Asilidae. Holcocephala calva are disturbed by slender twig ants, dragonflies, bumblebees, and honeybees and usually move backwards down the twig that they are on.

\section{ACKNOWLEDGMENTS}

The author thanks the staff of the St. Johns River Water Management District for the issuance of the Special Use Authorization that allows the study of robber flies in the Moses Creek Conservation Area (MCCA) and for their interest in the research.

I also thank the anonymous reviewers for their excellent and constructive comments on the manuscript.

\section{REFERENCES}

Back, E.A. (1909). The robber flies of America north of Mexico, belonging to the subfamilies Leptogastrinae and Dasypogoninae. Transactions of the American Entomological Society, 35, 137- 400.

Baker, N.T. \& Fischer, R.L. (1975). A taxonomic and ecologic study of the Asilidae of Michigan. The Great Lakes Entomologist, 8(2), 31-91.

Blanton, F.S. (1939). Collecting notes on the family Asilidae (Diptera). Bulletin of the Brooklyn Entomological Society, 34(5), 229-235.

Brimley, C.S. (1922). List of the robberflies (Asilidae, Diptera) of North Carolina. Entomological News, 33, 294-298.

Bromley, S.W. (1931). A preliminary annotated list of the robber flies of Ohio (Diptera: Asilidae). Ohio State University Museum Science Bulletin, 1, 3-19.

Bromley, S.W. (1946). Guide to the insects of Connecticut. Part VI. The Diptera or true flies of Connecticut. Third fascicle Asilidae. Connecticut State Geological and Natural History Survey Bulletin No. 69, 1-48.

Bromley, S.W. (1950). Florida Asilidae (Diptera) with description of one new species. Annals of the Entomological Society of America, 43(2), 227-239.

Candan, S., Suludere, Z., Hasbenli, A., Çağıran, N., Lavigne, R. \& Scarbrough, A. (2004). Ultrastructure of the chorion of Dioctria flavipennis Meigen, 1820 (Diptera: Asilidae: Stenopogoninae) compared with those of fourteen asilid species from the mid-Atlantic region of North American. Proceedings of the Entomological Society of Washington, 106(4), 811-825.

Carrera, M. (1958). Sobre o genero Dasyllis Loew, 1851 (Diptera, Asilidae) Papéis avulsos do Departamento de Zoologia, 13, 213-220.

Dennis, D.S. (1979). Ethology of Holcocephala fusca in Virginia (Diptera: Asilidae). Proceedings of the Entomological Society of Washington, 81(3), 366-378.

Dennis, D.S. (2014). Ethology of Holopogon phaeonotus Loew, 1874 (Diptera: Asilidae) in Northeastern Florida, U.S.A. Journal of the Entomological Research Society, 16(2), 141-158.

Dennis, D.S. (2016). Ethology of Promachus bastardii (Macquart, 1838) (Diptera: Asilidae) in Northeastern Florida, U.S.A. Journal of the Entomological Research Society, 18(3), 69-92.

Dennis, D.S. (2018). Ethology of Holopogon snowi Back, 1909 (Diptera: Asilidae) in Northeastern Florida, U.S.A. Journal of the Entomological Research Society, 20(1), 95-112.

Dennis, D.S. (2020). Ethology of Proctacanthus gracilis Bromley, 1928 (Diptera: Asilidae) in Northeastern Florida, U.S.A. Journal of the Entomological Research Society, 22(3), 255-273. 
Dennis, D.S. \& Lavigne, R.J. (1975). Comparative behavior of Wyoming robber flies II (Diptera: Asilidae). Agricultural Experiment Station University of Wyoming-Laramie Science Monograph No. 30, 68 pp.

Dennis, D.S., Lavigne, R.J., \& Dennis, J.G. (2012). Spiders (Araneae) as prey of robber flies (Diptera: Asilidae). Journal of the Entomological Research Society, 14(1), 65-76.

Douglass, J.K. \& Wehling, M.F. (2016). Rapid mapping of compound eye visual sampling parameters with FACETS, a highly automated wide-field goniometer. Journal of Comparative Physiology A, 202 (12), 839-851.

Drukewitz, S.H., Fuhrmann, N., Undheim, E.A.B., Blanke, A., Giribaldi, J., Mary, R., Laconde, G., Dutertre, S. \& von Reumont, B.M. (2018). A Dipteran's novel sucker punch: evolution of arthropod atypical venom with a neurotoxic component in robber flies (Diptera, Asilidae). Toxins, 10(1), 1-23.

Engineering ToolBox (2004). Illuminance-Recommended light level. Retrieved from https://www. engineeringtoolbox.com/light-level-rooms-d_708.html

Fabian, S.T., Sumner, M.E., Wardill, T.J., Rossoni, S., \& Gonzalez-Bellido, P.T. (2018). Interception by two predatory fly species is explained by a proportional navigation feedback controller. Journal of the Royal Society Interface, 15, 20180466.

Fisher, E.M. (2009). Chapter 45. Asilidae (robber flies, assassin flies, moscas cazadoras, moscas ladronas). In Brown, A. Borkent, J.M. Cumming, D.M. Wood, N.E. Woodley, \& Zumbado (Eds.). Manual of Central American Diptera (pp. 585-632). National Research Council of Canada, Research Press, Monograph Publishing Program.

Fisher, E.M. \& Wilcox, J. (1997, unpublished). Catalog of the robber flies (Diptera: Asilidae) of the Nearctic Region. California Department of Food \& Agriculture; Sacramento.

Geller-Grimm, F. (2021, January 4). Robber flies (Asilidae), database, catalog of species. Retrieved from http://www.geller-grimm.de/catalog.species.htm

Hull, F.M. (1962). Robber flies of the world. The genera of the family Asilidae. U.S. National Museum Bulletin, 224(1), 63-64.

Johnson, P.E. (1976). A preliminary investigation of the behavior of adult Holcocephala abdominalis (Say) (Diptera: Asilidae) in Putnam County, Indiana; with a description of the larvae and the eggs. M.S. Thesis, DePauw University, Greencastle, Indiana.

Lackey, R. (2016, January 28). Shedding Light on Lumens, Lux and Latitude. Retrieved from https://www. cined.com/shedding-light-lumens-lux-latitude/

Land, M.F. (1997). Visual acuity in insects. Annual Review of Entomology, 42, 147-177.

LaPierre, L.M. (2000). Prey selection and diurnal activity of Holcocephala oculata (F.) (Diptera: Asilidae) in Costa Rica. Proceedings of the Entomological Society of Washington, 102(3), 643-651.

Lavigne, R.J., Dennis, D.S., \& Gowen, J.A. (2000). Asilid literature update 1956-1976 including a brief review of robber fly biology (Diptera: Asilidae). Agricultural Experiment Station University of Wyoming Science Monograph 36, 93 pp.

Lavigne, R.J. \& Holland, F.R. (1969). Comparative behavior of eleven species of Wyoming robber flies (Diptera: Asilidae). Agricultural Experiment Station University of Wyoming Laramie Science Monograph No. 18, 61 pp.

Lehr, P.A. (1958). On the biology and behavior of robber flies (Asilidae-Diptera). Trudy Instituta Zoologii, Akademiya Nauk Kazakhstan. SSR, 8, 173-196. (In Russian).

Martin, C.H. \& Wilcox, J. (1965). Family Asilidae. In A., Stone, C.W., Sabrosky, W.W., Wirth, R.H., Foote, \& J.R. Coulson, A Catalog of the Diptera of America North of Mexico (pp. 360-401). U.S. Department of Agriculture, Agricultural Research Service, Agriculture Handbook No. 276.

McAtee, W.L. \& Banks, N. (1920). District of Columbia Diptera: Asilidae. Proceedings of the Entomological Society of Washington, 22(1-2), 13-33.

McGravy, K.W. \& Baxa, K.A. (2011). Diversity, seasonal activity and habitat associations of robber flies (Diptera: Asilidae) in west-central Illinois. American Midland Naturalist, 166, 85-97.

Morgan, K.R. \& Shelly, T.E. (1988). Body temperature regulation in desert robber flies (Diptera: Asilidae). Ecological Entomology, 13, 419-428. 
Ethology of Holcocephala calva (Loew, 1872) (Diptera: Asilidae) in Northeastern Florida

Morgan, K.R., Shelly, T.E., \& Kimsey, L.S. (1985). Body temperature regulation, energy metabolism, and wing loading in light-seeking and shade-seeking robber flies. Journal of Comparative Physiology, 155, 561-570.

Musso, J.J. (1968). Digestion extra-intestinale chez Stenopogon sabaudus F. et Machimus pilipes Meig. (Dipt. Asilidae). Bulletin de la Société Zoologique de France, 93(3), 487-497.

Nation, J.L. (2008). Eyes and vision. In Capinera, J.L. (Ed.) Encyclopedia of Entomology (pp. 1381-1392), $2^{\text {nd }}$ Edition. Springer Netherlands.

Scarbrough, A.G. (1974). A faunistic study of Asilidae (Diptera) at three locations in northern Baltimore County, Maryland: incidence, relative abundance and seasonal distribution. Proceedings of the Entomological Society of Washington, 76(4), 385-396.

Scarbrough, A.G. (1982). Coexistence in two species of Holcocephala (Diptera: Asilidae) in a Maryland habitat: predatory behavior. Proceedings of the Entomological Society of Washington, 84(2), 349-365.

Wardill, T.J., Fabian, S.T., Pettigrew, A.C., Stavenga, D.G., Nordström, K., \& Gonzalez-Bellido, P.T. (2017). A novel interception strategy in a miniature robber fly with extreme visual acuity. Current Biology, 27, 854-859.

Received: April 15, 2021

Accepted: September 08, 2021 